\title{
FISH DIVERSITY AT THE VICINITY OF HATIYA ISLAND, BANGLADESH
}

\author{
Sourav Mahmood, Bijoya Paul, Mohammad Raknuzzaman, \\ Md. Habibullah-Al-Mamun* \\ Department of Fisheries, University of Dhaka, Dhaka 1000, Bangladesh
}

\begin{abstract}
This study was aimed to identify the present status and threats on the fish diversity of Hatiya Island, Noakhali, Bangladesh. Five sampling stations were at Chairman ghat, Katakhali ghat, Tamruddin ghat, Burirdona ghat, Domar Bazar. Data were collected using questionnaire interviews (QI), focus group discussions (FGD), and key informant interviews (KII). A total of 38 fish species were recorded belonging to 9 orders and 21 families. Siluriformes was the most abundant order (38\%), whereas Cyprinidae was the richest family (18.42\%). Based on IUCN red list of threatened species 2015, 26\% species was categorized as Locally Threatened in Bangladesh, following 13\% as Vulnerable, $13 \%$ as Endangered, $63 \%$ as Least concerned, 3\% as Data Deficient (DD) and $8 \%$ was Not Threatened (NT). Overexploitation, water pollution, habitat degradation and climate change were identified as the major threats for declining of fish diversity in the study area. This study recommends sustainable fisheries management, restocking economically important fish species, establishment of sanctuary, maintenance of fishing gears, control of pollution, and the implementation of the fish act for conservation of fish biodiversity of the Hatiya Island, Noakhali.
\end{abstract}

Key words: Fish; diversity; status, Threats; Hatiya Island, Bangladesh

\section{INTRODUCTION}

Bangladesh, a land of rivers, possess the world's largest flooded wetland and the third largest aquatic biodiversity in Asia after China and India (Shamsuzzaman et al. 2017). The country's favorable geographic position is a key factor of having plenty of fisheries resources. A total number 265 freshwater fish species are reported in Bangladesh (Rahman 2005, Siddiqui et al. 2007). Moreover, 475 marine fish species, 24 fresh water prawn, 36 marine shrimp species and crab, mussel, snail, turtle, etc. are available in the water body of Bangladesh (DoF 2018). The fisheries sector is playing a crucial role in the socioeconomic development of Bangladesh by creating employment, engaging women, providing nutrition as well as earning from overseas by exporting fish, shrimps

\footnotetext{
*Author for correspondence: <almamunhabib@du.ac.bd> C2020 Zoological Society of Bangladesh DOI: https://doi.org/10.3329/bjz.v48i1.47875
} 
and other fisheries products. This promising sector contributes significant percentages to the national GDP (3.57\%) and the agricultural GDP $(25.3 \%)$ in Bangladesh (DoF 2018).

The total fish production of Bangladesh is 41.34 lakh MT and more than 11 percent of the total population of Bangladesh are directly or indirectly engaged in this sector

for their livelihoods (DoF 2018). In the economic year of 2017-18, foreign currencies equivalent of 4309.94 crore taka were earned by exporting 68935.45 MT fish and fisheries product (DoF 2018).

Southern coastal waters including 19 districts and 147 upazillas and the Exclusive Economic Zone (EEZ) are recognized as one of the most important aquatic biodiversity hotspots in Bangladesh (Minar et al. 2013, Hanif et al. 2015). Hatiya is one of the largest coastal islands in Bangladesh where 10,500 fishermen live. The island is located at the mouth of the Meghna River in the northern part of the Bay of Bengal (BoB).It is positioned in the southern part of greater Noakhali district(Azam et al. 2014). It covers an area of $1,508 \mathrm{~km}^{2}$. The area is exposed to frequent cyclones and regular destructive ocean waves (Encyclopedia Britannica, 2012). Various types of habitats are distinguishable in the area of Hatiya and its surroundings including intertidal immense mudflats, creeks inside mangroves, grassland, reed land, sand beaches, sand flats, sand dunes and several channels. These diversities of habitats make the coastal aquatic ecosystem resourceful with different types of aquatic plants, fish and shellfish including other aquatic or semi-aquatic organisms. Nonetheless, fishes are the most valuable component and the major source of dietary protein for the local community. Particularly fishing and fisheries related activities are the main business in the Hatiya Island and contribute significantly to its economy. Nevertheless, habitat degradation, over-exploitation, and aquatic pollution have led to radical declines in fish stock and diversity which ultimately threaten the people's livelihood. Indiscriminate killing, overexploitation, destructive fishing gear and methods, pollution and lack of proper management initiatives causes the fish biodiversity of Hatiya to be in great danger. Many of the fishes become vulnerable, endangered, or critically endangered. However, few research works have been conducted on the Hatiya Island fish biodiversity. But there is no complete list/study of existing fish species with updated conservation status. For this reason, it is very difficult to understand the present status of fishes in the Hatiya Island. Considering the lack of baseline information on the diversity of fish species, this study was aiming to explore the prevailing fish species composition of Hatiya island. The specific objectives of the present study were to (i) assess the fish diversity including threatened fishes in Hatiya Island (ii) identify threats to fish diversity and suggest recommendations to improve present conservation status of threatened fishes (iii) to disseminate baseline information for the status of fish diversity the Hatiya island. 
MATERIAL AND METHODS

Study area: Fish biodiversity data were collected from five stations of Hatiya Island such as Chandnandi (Chairman ghat), Jahajmara (Katakhali ghat), Tamruddin (Tamruddin ghat), Burirchar (Burirdona ghat), and Nijhum dwip (Domar Bazar) (Fig. 1) in April 2018.

Data collection: Primary information about fish species was collected through questionnaire interviews (QI) by a face to face interview method. The questionnaire was formulated as a set of both closed and open-ended questions including general information such as local name, distribution and availability of the fish species, fishing gears and crafts being used, major factors threatening the fisheries diversity, etc. The respondents for the questionnaire interview were fishermen, fishing boat owners, fish traders, retailers and other local people from the study areas. To justify the primary information, a crosscheck was done by the key informant interviews (KII) such as Upazila Fisheries Officer (UFO), District Fisheries Officers (DFO), experienced fishermen and relevant NGO workers. Focus group discussion (FGD) was also done in fish landing centers, fish markets, and fisher's village of those selected surveyed areas. Secondary data to support the primary information was collected from various commune's annual reports and documents. Different field guides were used for the identification of species in the field. Photographs were taken for future identification and documentation.

Determination of conservation status: The conservation status of the recorded fish specimen was determined following the database of the Red List of Bangladesh (IUCN Bangladesh, 2015).

Analysis of data: The collected data were firstly scrutinized carefully and then summarized into tabulation. To ensure the accuracy of the data entry, the result sheets were compared carefully with preliminary data sheets and the original questionnaire. The data were finally processed and analyzed with Microsoft Excel Professional version 2013.

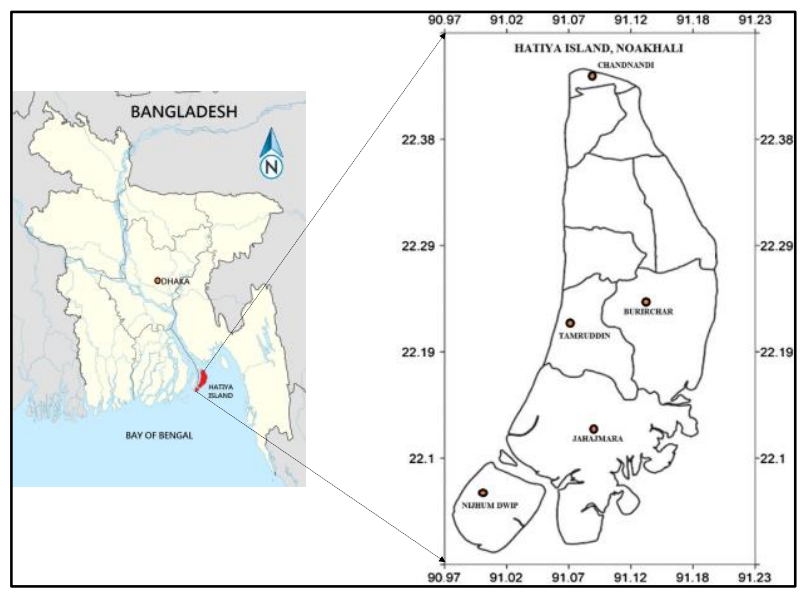

Fig. 1. Map showing the study areas of the Hatiya Island, Noakhali. 


\section{RESULTS AND DISCUSSION}

Fish diversity status of the Hatiya Island: In the present study, a total of 38 fish species under 9 orders and 21 families were recorded during the survey period from 5 study areas. List of fish species with scientific name, local name and distribution among the study areas is shown in Table 1. Siluriformes was the most abundant order consisting 38\% of the total fish species recorded followed by Perciformes (19\%), Cypriniformes (10\%), Clupeiformes (10\%), Beloniformes (5\%), Channiformes (5\%), Gobiiformes (5\%), Osteoglossiformes $(5 \%)$, and Synbranchiformes (5\%) (Fig. 2). Present study differs with the findings of the previous studies: Perciformes was recorded as the most dominant order from the Meghna river, Chandpur (Pramaniket al. 2017), Payra river, Patuakhali (Islam et al. 2015) and from the southern coastal districts of Bangladesh (Hanif et al. 2015); this discrepancies might be due to suitability of the habitats for the fish species of Perciformes at those study rivers as well as due to the short survey period of the present study.

Cyprinidae was the most dominant family (18.4\%) followed by Bagridae (10.5\%), Channidae (7.9\%). On the other hand, Cobitidae, Siluridae, Gobidae, Engraulidae, Clupeidae, Notopteridae comprised $5.3 \%$ each whereas contribution of Sisoridae, Heteropneustidae, Claridae, Schilbeidae, Anabantidae, Sciaenidae, Nandidae, Mastacembelidae, Polynemidae, Belonidae, Pangasidae, Ailiidae were $2.6 \%$ each (Fig. 3). Several previous studies have found Cyprinidae as the richest family from different areas of Bangladesh: Chandpur, Noakhali, Laxmipur, Pirojpur, Bhola, Patuakhali, Barguna, Nazirhat Bridge, Sattarghat Bridge and Garduara of Chittagong (Pramanik et al., 2017; Ullah et al., 2016; Hanif et al., 2015; Islam et al., 2015; Alam et al., 2013) which is consistent with the present study.

Among the fish species recorded in this study, 23\%was recorded from Chairman Ghat, $20 \%$ fish species were recorded from both Katakhali Ghat and Tamruddin Ghat, 19\% fish species were recorded from Burirdona Ghat and 18\% fish species were recorded from Domar Bazar (Fig. 4).

During the present survey, the respondents reveal that many fish species once abundant on the Hatiya Island, Noakhali are now becoming rare in their catch. The International Union for Conservation of Nature (IUCN), a recognized global authority for assessing the risk of species extinction, identified 64 threatened fish species comprising 9 species as critically endangered, 30 species Endangered and 25 species as Vulnerable out of 253 freshwater fish species from the whole country (IUCN Bangladesh, 2015). Among the threatened species, 10 fish species have been found at a risk of being threatened in the present study: 5 fish species (13\%) were endangered (EN) and 5 fish species (13\%) were vulnerable (VU); also 24 fish species (63\%) were Least concerned, 1 fish species (3\%) was Data Deficient (DD) and 3 fish species (8\%) were not threatened (NT) based on IUCN red list of threatened species 2015 (Table 1, Fig. $5)$. 
A number of studies have found threatened species in the southern coastal district of Bangladesh: Local conservation status of coastal areas of Noakhali and Laxmipur region showed that the highest percentage was recorded as not threatened (46\%) followed by Vulnerable (14\%), Endangered (13\%) and Critically Endangered (8\%). Only 19\% fish species were occupied by Data Deficient category (Ullah et al., 2016). Pramanik et al. (2017) conducted a comprehensive study on the Meghna river, Chandpur district and found 21 threatened fish species: 11 species (10.28\%) were recorded as Vulnerable (VU), 8 species $(7.48 \%)$ as Endangered (EN) and 2 species (2\%) as Critically Endangered (CR).Interestingly, 4 endangered species and 4 vulnerable species recorded in these two previous studies are similar with the present study findings: Rita rita(EN), Ompok pabda (EN), Chitala chitala (EN), Pangasius pangasius (EN), Pethia ticto (VU), Wallago attu (VU), Notopterus notopterus (VU), and Gudusia chapra (VU).Islam et al. (2015) also identified a similar composition of threatened species from the Payra river, Patuakhali. Hanif et al. (2015) also recorded similar threatened species from Pirojpur, Bhola, Patuakhali and Barguna, Southern coastal district of Bangladesh: Rita rita (EN), Ompok pabda (EN), Chitala chitala (EN), Pangasius pangasius (EN), Wallago attu (VU), Notopterus notopterus (VU), Gudusia chapra(VU).

Rahman (2005) conducted a comprehensive study and identified 265 freshwater fish species belonging to 55 family from the entire Bangladesh. The present survey recorded 38 fish species from Hatiya Island, Noakhali which represent $15 \%$ of the country's total freshwater fish species. A number of studies have been conducted on fish biodiversity in the southern coastal region of Bangladesh: Pramanik et al. (2017) conducted a study on Meghna river, Chandpur District and found 107 fish species belonging to 13 order, 36 family; Ullah et al. (2016)conducted a study on Coastal areas of Noakhali and Laxmipur and found 63 fish species belonging to 22 family; Hanif et al. (2015) found 98 fish species under 13 order and 48 family from Pirojpur, Bhola, Patuakhali and Barguna; Islam et al. (2015) found 114 fish species under 12 order and 36 family from Payra river, Patuakhali district; Hossain et al., (2014) found 128 fish species under 34 family from greater Noakhali; Alam et al. (2013) found 63 fish species under 24 family from Nazirhat Bridge, Sattarghat Bridge and Garduara, Upper Halda river, Chittagong; Hossain et al. (2012) found 53 fish species from Ramgati, Bhola Sadar, Daulatkhan, Burhanuddin, Noakhali Sadar, Hatiya,Tazumudin, Meghna river estuary. In comparison with the above mentioned Southern coastal study sites in Bangladesh, the present study area, Hatiya Island (38 fish species) is less in fish diversity; this is probably due to limited study area and short sampling period compared to other study.

Threats to fish biodiversity: Overexploitation, water pollution, change of river course, siltation in water bodies, destruction or degradation of habitat, discharges from industries and municipal sewerage, introduction of exotic fish, climate change are the major threats to fisheries biodiversity in Bangladesh (IUCN Bangladesh, 2015). In addition, intense tourism and discharges from shipping industries are the major causes of degrading fish habitats in southern 


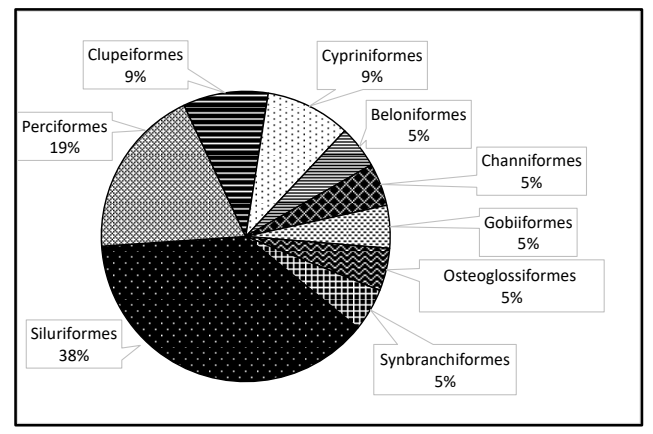

Fig.2. Order wise percentage of fish species in the Hatiya island, Noakhali

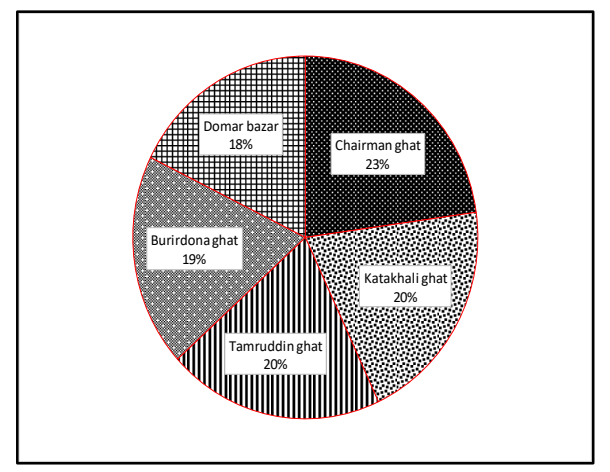

Fig. 4. Percentage variation of fish species in the Hatiya Island, Noakhali.

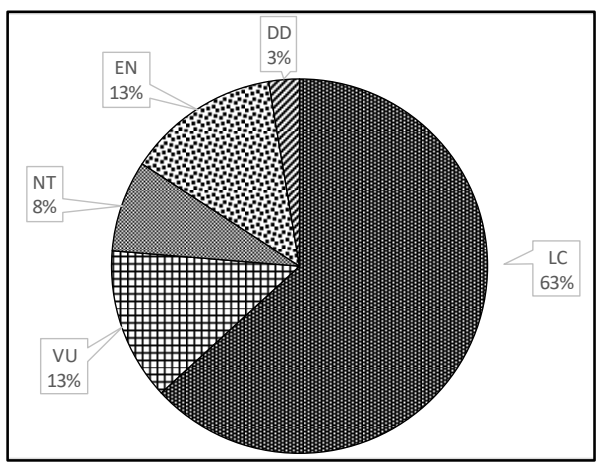

Fig. 5. Conservation status of the fish species found in the studied area (IUCN Bangladesh, 2015). In figure: Data

Deficient (DD), Least Concern (LC), Near Threatened (NT), Vulnerable (VU), Endangered (EN).

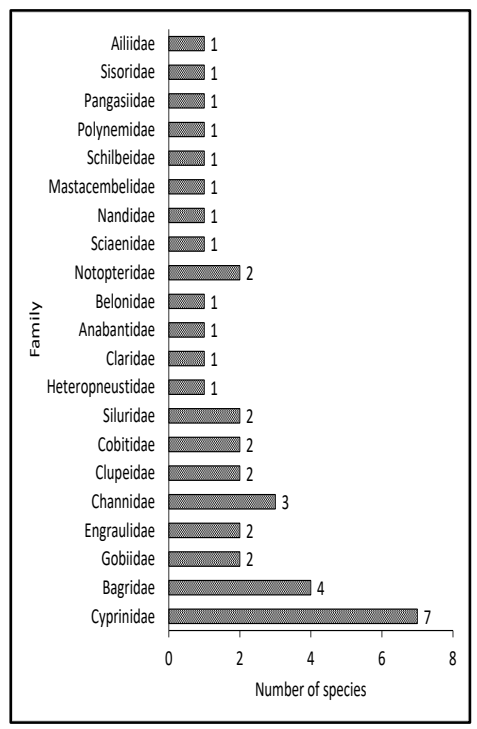

Fig. 3. Family wise fish species diversity in the Hatiya island, Noakhali.

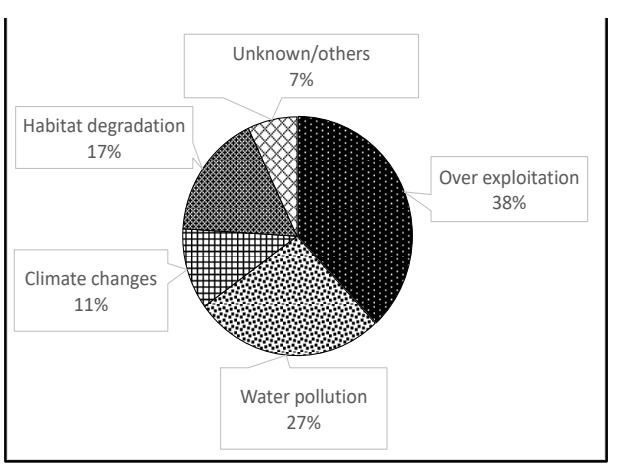

Fig. 6. Threats to the fish biodiversity in the Hatiya Island, Noakhali. 
Table 1. Finfish species found in the Hatiya island, Noakhali

\begin{tabular}{|c|c|c|c|c|c|c|c|}
\hline \multirow{2}{*}{ Family and Species } & \multirow{2}{*}{$\begin{array}{l}\text { Local } \\
\text { name }\end{array}$} & \multicolumn{5}{|c|}{ Sampling stations ${ }^{a}$} & \multirow{2}{*}{$\begin{array}{c}\text { Conservation } \\
\text { Status (IUCN } \\
2015)^{b}\end{array}$} \\
\hline & & $\mathbf{C G}$ & $\mathbf{K G}$ & TG & BG & DB & \\
\hline \multicolumn{8}{|l|}{ Cyprinidae } \\
\hline Labeo bata & Bata & $\checkmark$ & & & $\checkmark$ & & $\mathrm{LC}$ \\
\hline Labeo rohita & Rui & $\checkmark$ & $\checkmark$ & $\checkmark$ & $\checkmark$ & $\checkmark$ & $\mathrm{LC}$ \\
\hline Pethia ticto & Tit Punti & & $\checkmark$ & & & & VU \\
\hline Gibelion catla & Catla & $\checkmark$ & & $\checkmark$ & & $\checkmark$ & $\mathrm{LC}$ \\
\hline Amblpharyngodon mola & Mola & $\checkmark$ & & & & $\checkmark$ & $\mathrm{LC}$ \\
\hline Labeo calbasu & Kalibaus & $\checkmark$ & & $\checkmark$ & & & $\mathrm{LC}$ \\
\hline Parluciosoma daniconius & Darkina & & & $\checkmark$ & & $\checkmark$ & $\mathrm{LC}$ \\
\hline \multicolumn{8}{|l|}{ Cobitidae } \\
\hline Lepidocephalus guntea & Gutum & $\checkmark$ & & & $\checkmark$ & & $\mathrm{LC}$ \\
\hline Botia dario & Rani & & $\checkmark$ & & & $\checkmark$ & EN \\
\hline \multicolumn{8}{|l|}{ Bagridae } \\
\hline Mystus cavasius & Ghosha & & $\checkmark$ & $\checkmark$ & & & NT \\
\hline Mystus vittatus & Tengra & $\checkmark$ & & & & $\checkmark$ & $\mathrm{LC}$ \\
\hline Aorichthys aor & Aor & & $\checkmark$ & & & & VU \\
\hline Rita rita & Rita & $\checkmark$ & & $\checkmark$ & & & EN \\
\hline \multicolumn{8}{|l|}{ Siluridae } \\
\hline Ompok pabda & Pabda & $\checkmark$ & & & $\checkmark$ & $\checkmark$ & EN \\
\hline Wallago attu & Boal & & $\checkmark$ & & & & VU \\
\hline \multicolumn{8}{|l|}{ Heteropneustidae } \\
\hline Heteropneustes fossilis & Shing & $\checkmark$ & & & $\checkmark$ & $\checkmark$ & $\mathrm{LC}$ \\
\hline \multicolumn{8}{|l|}{ Claridae } \\
\hline Clarias batrachus & Magur & & $\checkmark$ & & $\checkmark$ & & $\mathrm{LC}$ \\
\hline \multicolumn{8}{|l|}{ Schilbeidae } \\
\hline Pseudeutropius atherinoides & Batashi & $\checkmark$ & & & $\checkmark$ & & $\mathrm{LC}$ \\
\hline \multicolumn{8}{|l|}{ Pangasiidae } \\
\hline Pangasius pangasius & Pangus & & & $\checkmark$ & & $\checkmark$ & EN \\
\hline \multicolumn{8}{|l|}{ Sisoridae } \\
\hline Bagarius yarrelli & Baghair & $\checkmark$ & & $\checkmark$ & & & $\mathrm{DD}$ \\
\hline \multicolumn{8}{|l|}{ Ailiidae } \\
\hline Ailia punctata & Kajuli & & & $\checkmark$ & & & $\mathrm{LC}$ \\
\hline \multicolumn{8}{|l|}{ Engraulidae } \\
\hline Tenualosa ilisha & Ilish & $\checkmark$ & $\checkmark$ & $\checkmark$ & $\checkmark$ & $\checkmark$ & $\mathrm{LC}$ \\
\hline Setipinna phasa & Phasa & & & $\checkmark$ & & & LC \\
\hline
\end{tabular}




\begin{tabular}{|c|c|c|c|c|c|c|c|}
\hline Family and Species & $\begin{array}{l}\text { Local } \\
\text { name }\end{array}$ & \multicolumn{5}{|c|}{ Sampling stations ${ }^{a}$} & $\begin{array}{l}\text { Conservation } \\
\text { Status (IUCN } \\
\end{array}$ \\
\hline Gadusiachapra & Chapila & $\checkmark$ & $\checkmark$ & $\checkmark$ & $\checkmark$ & $\checkmark$ & VU \\
\hline Coricasoborna & Kachki & & $\checkmark$ & & & & LC \\
\hline \multicolumn{8}{|l|}{ Anabantidae } \\
\hline Anabas testudineus & Koi & $\checkmark$ & & & $\checkmark$ & & LC \\
\hline \multicolumn{8}{|l|}{ Sciaenidae } \\
\hline Pamapama & Poa & & $\checkmark$ & & & & LC \\
\hline \multicolumn{8}{|l|}{ Nandidae } \\
\hline Nandus nandus & Meni & $\checkmark$ & & & $\checkmark$ & & NT \\
\hline \multicolumn{8}{|l|}{ Polynemidae } \\
\hline Polynemusparadiseus & Tapasi & & $\checkmark$ & & $\checkmark$ & & LC \\
\hline \multicolumn{8}{|l|}{ Gobiidae } \\
\hline Taenioidescirratus & Chewa & $\checkmark$ & & $\checkmark$ & & & $\mathrm{LC}$ \\
\hline Glossogobiusgiuris & Bailla & & $\checkmark$ & & & $\checkmark$ & LC \\
\hline \multicolumn{8}{|l|}{ Channidae } \\
\hline Channa punctatus & Taki & $\checkmark$ & & & $\checkmark$ & & LC \\
\hline Channa orientalis & TeloTaki & & $\checkmark$ & & & & LC \\
\hline Channa striatus & Shol & & & $\checkmark$ & & $\checkmark$ & LC \\
\hline \multicolumn{8}{|l|}{ Belonidae } \\
\hline Xenentodon cancila & Kaikka & & $\checkmark$ & & & & LC \\
\hline \multicolumn{8}{|l|}{ Notopteridae } \\
\hline Chitala chitala & Chital & & $\checkmark$ & & $\checkmark$ & & EN \\
\hline Notopterus notopterus & Foli & & & $\checkmark$ & & & VU \\
\hline \multicolumn{8}{|l|}{ Mastacembelidae } \\
\hline Macrognathus aral & $\begin{array}{l}\text { Tara } \\
\text { Baim }\end{array}$ & & & $\checkmark$ & & $\checkmark$ & NT \\
\hline
\end{tabular}

coastal area of Bangladesh. This coastal area is serving as afeeding ground, seasonal breeding and migratory routes for a large number of anadromous, catadromous, and diadromous fishes (Sharker et al., 2015; Hanif et al., 2015; Alam and Xiangmin, 2018). 
In the present study, 4 major reasons were identified as threats of declining fish biodiversity: the overexploitation of fishes was 38\% responsible for the biodiversity destruction in the Hatiya Island followed by a $27 \%$ loss of fish biodiversity due to water pollution, habitat degradation resulted in $17 \%$ of loss and climate change caused $11 \%$ of fish diversity loss of the island (Fig. 6).Other $7 \%$ threats to the fish diversity in the Hatiya Island are probably due to sedimentation in water bodies, eutrophication, changes in river course etc. Islam et al. (2015) also reported that indiscriminate fishing of fish larvae and juveniles, siltation and pollution were the major causes of the declination of fish diversity in the Payra River (Patuakhali, Bangladesh).

\section{CONCLUSIONS}

The present study is reporting the current fish diversity of the Hatiya Island, identifying major threats to fish diversity and providing recommendations for fish biodiversity conservation. A total of 38 fish species and 10 threatened fish species out of 38 recorded from the Hatiya Island indicates an alarming threat to the present conservation status of fishes in Bangladesh. Some recommendations would be mentioned from the study for policy making, implementation, and conservation of fish diversity in the Hatiya Island: banning indiscriminate killing of fish fry and fingerling; controlling over destructive fishing gears and crafts; establishing and managing fish sanctuaries on fish breeding and nursery ground in that area; controlling over pollution around the Island; research should be carried out on the conservation of threatened fishes; introducing awareness raising program on conservation among fisherman, fish retailers, fish traders and local people.

Acknowledgements: This study was supported by the research grant (2017-18) from the University Grants Commission of Bangladesh (Grant \# Regi/Admin3/67829-31). Furthermore, we are thankful for the kind help from the students of the Department of Fisheries, University of Dhaka, Bangladesh, during the field survey.

\section{LITERATURE CITED}

ALAM, M.S., HOSSAIN, M.S., MONWAR, M.M. and HOQUE,M.E. 2013. Assessment of fish distribution and biodiversity status in Upper Halda River, Chittagong, Bangladesh. Int. J. Biodivers. Conserv. 5(6): 349-357. DOI: 10.5897/IJBC2013.0555.s

ALAM, M.W. and XIANGMIN, X. 2018. Marine pollution prevention in Bangladesh: a way forward for implement comprehensive national legal framework. Thalassas: An Int. J. Mar. Sci. 1-11. DOI: 10.1007/s41208-018-0078-x.

AZAM, A.K.M.S., SAHA, D.,ASADUJJAMAN, MD., MAHBUB, K.R. and MINAR,M.H. 2014. Fishing gears and crafts commonly used at Hatiya Island: A coastal region of Bangladesh. Asian J. Agric. Res. 8 (1): 51-58.

DIAZ, S., FARGIONE, J., CHAPIN, F.S. andTILMAN, D. 2006. Biodiversity loss threatens human well-being. PLoS Biol. 4: 1300-1305. 
DOF 2011. Fish Fortnight Compendium 2011. Department of Fisheries, Ministry of Fisheries and Livestock, Dhaka, Bangladesh.

ENCYCLOPEDIA BRITANNICA 2012. Hatiya Islands. Encyclopedia Britannica Online. Encyclopedia Britannica Inc.

HANIF, M.A., SIDDIK, M.A.B., CHAKLADER, M.R., NAHAR, A. and MAHMUD, S. 2015. Fish diversity in the southern coastal waters of Bangladesh: present status, threats and conservation perspectives. Croat. J. Fish. 73: 148-161. DOI: 10.14798/73.4.848.

HILBORN, R., QUINN, T.P., SCHINDLER, D.E. andROGERS, D.E. 2003. Biocomplexity and fisheries sustainability. Ecol. Monogr. 75:3-36.

HOSSAIN, M.M. and ISLAM, M.H. 2006. Status of the biodiversity of St. Martin's Island, Bay of Bengal, Bangladesh. Pak. J. Mar. Sci. 15(2): 201-210.

HOSSAIN, M.S., DAS, N.G.,SARKER, S. and RAHAMAN, M.Z. 2012. Fish diversity and habitat relationship with environmental variables at Meghna river estuary, Bangladesh. Egypt. J. Aquat. Res. 38: 213-226. DOI:10.1016/j.ejar.2012.12.006

HOSSAIN, M.S., SARKER, S.,RAHAMAN,M.Z. and RAHMAN,M.M.2014. Freshwater fish diversity at greater Noakhali, Bangladesh. CMU J. Nat. Sci. 13(2):207. Doi: 10.12982/cmujns.2014.0032.

ISLAM, M.A., HOSSAIN, M.M.,AHSAN,M.E. and NAHAR, A. 2015. Status and current worries of fish diversity in the Payra river, Patuakhali, Bangladesh. Int. J. Fish. Aquat. Stud. 2(3): 160-165.

ISLAM, M.F., 2009. Swapner NijhumDwip. Anjuman Ara publishing, Noakhali, Bangladesh.

DoF 2018. National Fish Week 2018 Compendium (in Bengali). Department of Fisheries, Ministry of Fisheries and Livestock, Bangladesh. p.160.

IUCN Bangladesh, 2013. Red book of threatened fishes of Bangladesh, IUCN- The world conservation union. pp.12-116.

IUCN Bangladesh, 2015. Red List of Bangladesh. Vol. 5. Freshwater Fishes. IUCN (International Union for Conservation of Nature), Bangladesh Country Office, Dhaka, Bangladesh, pp. xvi+360.

MACE, G., MASUNDIRE, H., BAILLIE, J., RICKETTS, T., BROOKS, T. 2005. Biodiversity. In: Hassan, R., Scholes, R., Ash, N. (Eds.), Ecosystems and human well-being: current state and trends (findings of the condition and trends working group). Island, pp.77-122.

MOYLE, P.E. and LEIDY, R.A. 1992. Loss of biodiversity in aquatic ecosystems: evidence for fish fauna. Chapman and Hall, New York.

PRAMANIK, M.M.H., HASAN, M.M.,BISSHAS, S.,HOSSAIN, A.B.M.A and BISWAS, T.K. 2017. Fish biodiversity and their present conservation status in the Meghna river of Bangladesh. Int. J. Fish. Aquat. Stud. 5(1): 446-455.

RAHMAN, A.K.A. 2005. Freshwater fishes of Bangladesh. Zoological Society of Bangladesh, Department of Zoology, University of Dhaka, Dhaka, Bangladesh 263. Second edition.

RAMOS, S., COWEN, R.K., RE', P., BORDALO, A.A. 2006. Temporal and spatial distribution of larval fish assemblages in the Lima estuary (Portugal). Estuarine, Coast. Shelf Sci. 66, 303-14. 
SHAMSUZZAMAN, M.M., ISLAM,M.M.,TANIA, N.J., AL-MAMUN, M.A., BARMAN, P.P., XU, X., 2017. Fisheries resources of Bangladesh: present status and future direction. Aquac. Fish. 2:145-156.

SHARKER, M.R., SIDDIK, M.A., NAHAR, A.,SHAHJAHAN, M. and FAROQUE,A.A.L. 2015. Genetic differentiation of wild and hatchery populations of Indian major carp Cirrhinuscirrhosus in Bangladesh. J. Environ. Biol. 36(5):1223.

SIDDIQ, A.B., SAHA, D.,RAHMAN,M. and HOSSAIN,M.B. 2013. Fishing gears of the Meghna river estuary of Chandpur region, Bangladesh. Trends Fish. Res. 2(1).

SIDDIQUI, K.U., ISLAM, M.A., KABIR, S.M.H., AHMAD, M., AHMED, A.T.A., RAHMAN, A.K.A., HAQUE, E.U., AHMED, Z.U., BEGUM, Z.N.T., HASAN, A., KHONDKER, M. and RAHMAN, M.M. (eds.). 2007. Encyclopedia of Flora and Fauna of Bangladesh. Vol. 23. Freshwater Fishes. Asiatic Society of Bangladesh, Dhaka, pp.300.

ULlAH, M.A., UDDIN, M.N., HOSSAIN, M.S., HOSSAIN, M.B. and HOSSAIN, M.A. 2016. Fish diversity in three selected areas of mid-coastal region, Bangladesh. J. Fish. Aquat. Sci. 11: 174184.

(Manuscript received on 5 August, 2019 revised on 25 February, 2020) 